\title{
Phosphorus Reduces Aluminum Toxicity in Oil Tea Roots by Regulating the Cell Wall Components and Antioxidant Defense System
}

\author{
Xinjing Qu, Jiao Liao, Chenhui Zhang and Jun Yuan* \\ Key Laboratory of Cultivation and Protection for Non-Wood Forest Trees, Ministry of Education, Central South University of \\ Forestry and Technology, Changsha, Hunan, China \\ For correspondence: yuanjun@csuft.edu.cn; Xinjingqu@126.com \\ Received 26 August 2020; Accepted 12 November 2020; Published 25 November 2021
}

\begin{abstract}
Aluminum ( $\mathrm{Al}$ ) toxicity is one of the most important impeding factors for plant growth and productivity in acidic soils. Phosphorus (P) application may alleviate $\mathrm{Al}$ stress in many plants. In this study we investigated the effect of $\mathrm{P}$ on $\mathrm{Al}$ toxicity in cell wall components and oxidative stress and to explore the underlying mechanisms in oil tea (Camellia oleifera Abel.) roots. Results indicated that Al toxicity severely inhibited root elongation, changed cell wall components, and caused oxidative damage to the roots of oil tea. However, $\mathrm{P}$ supply reduced the adsorption of $\mathrm{Al}$ in the cell wall by decreasing the demethylesterfied pectin content and hemicellulose 1 content that decreased the $\mathrm{Al}$ binding sites. Moreover, the addition of $\mathrm{P}$ alleviated the inhibition of xyloglucan endotransglucosylase and endo- $\beta$-1,4-glucanases activities under Al stress, which enhanced the loosening of the cell wall. $\mathrm{P}$ addition reduced the activities of polyphenol oxidase and phenylalanine ammonia lyase and enhanced the activities of reactive oxygen species scavenging enzymes, which reduced the oxidative damage caused by $\mathrm{Al}$ toxicity. The results reveal important mechanisms of $\mathrm{P}$-induced mitigation of $\mathrm{Al}$ stress in oil tea roots that might be useful in the cultivation of plants on acidic soils. (C) 2021 Friends Science Publishers
\end{abstract}

Keywords: Al stress; P deficiency; Pectin; Hemicellulose; Oxidative stress

\section{Introduction}

Aluminum (Al) toxicity is one of the most important factors inhibiting plant growth in acidic soils, and about $60 \%$ of acidic soils are located in the subtropics and tropics (Kochian et al. 2004). An important symptom of $\mathrm{Al}$ stress is the inhibition of root elongation, which can occur within a short period after Al supply (Kopittke et al. 2015). In addition, long-term Al stress can cause disorder of the ROS scavenging system, leading to the accumulation of the superoxide anion and $\mathrm{H}_{2} \mathrm{O}_{2}$, membrane lipid peroxidation, protein degradation, and cell death (Yu et al. 2018; Riaz et al. 2018a). Root tips are the primary target of $\mathrm{Al}$ stress, which accumulate more $\mathrm{Al}$ than any other part (Kopittke et al. 2015). Although Al stress induces various Al-tolerance mechanisms in plants, such as release of secret organic acids to chelate $\mathrm{Al}$ in the rhizosphere, compartmentalize $\mathrm{Al}$ in vacuoles, and increase the rhizosphere $\mathrm{pH}$ to decrease $\mathrm{Al}$ adsorption to roots in most plants (Kochian et al. 2004), Al in roots mainly accumulates in the cell wall because pectin and hemicellulose provide negatively charged sites to bind it (Yang et al. 2011). Additionally, Al accumulation in the cell wall changes the properties of cell wall components, resulting in rigid cell walls and limited cell elongation, which ultimately inhibit root elongation (Safari et al. 2018). However, the addition of other substances can reduce the accumulation of $\mathrm{Al}$ in cell walls, such as boron application, which can increase the degree of pectin methyl-esterification in roots of trifoliate orange to decrease $\mathrm{Al}$ accumulation (Riaz et al. 2018b). Similarly, the addition of putrescine decreases the pectin content, hemicellulose content, and pectin methyl esterase (PME) activity, which reduces the $\mathrm{Al}$ content in roots and promotes root growth (Zhu et al. 2019).

Phosphorus $(\mathrm{P})$ is a vital nutrient element involved in the synthesis of macromolecules, such as phospholipids, nucleic acids, NADP, and ATP; however, the bioavailable P content of plants is very low in acidic soils. P deficiency limits plant growth and influences the cumulative patterns of amino acids, organic acids, and carbohydrates in roots (Mo et al. 2019). Reportedly, the P deficiency may enhance Al toxicity on the inhibition of plant growth by affecting wall properties. For instance, Nagarajah et al. (1970) reported that pectin in the cell walls of roots can bind Fe and Al through ligand exchange of phosphate to solubilize $\mathrm{P}$ from in acidic soils. Zhao et al. (2018) and Zhu et al. (2015) reported that short term P-deficiency caused an increase in the pectin content and a decrease in the degree of pectin methyl-esterification, which increased the binding ability of 
cell wall to $\mathrm{Fe}$ and $\mathrm{Al}$. The adsorption of $\mathrm{Al}$ by cell walls caused by $\mathrm{P}$ deficiency undoubtedly aggravates $\mathrm{Al}$ stress in the root system. $\mathrm{P}$ addition has long been considered an important factor to alleviate $\mathrm{Al}$ toxicity because it may enhance the utilization of nutrient elements and reduce the $\mathrm{Al}$ content in plants (Yu et al. 2018).

Oil tea (Camellia oleifera Abel.) is an important edible oil tree that has been cultivated in southern China for more than 2300 years (Yang et al. 2016). At present, the planting area of oil tea in China is greater than four million hectares, mostly distributed in acidic soils in southern China. In these areas, $\mathrm{Al}$ toxicity and $\mathrm{P}$ deficiency are two crucial factors limiting the production of oil tea as a result of strong mineral leaching and acid deposition. Zhou et al. (2019) reported that the supply of $\mathrm{P}$ can decrease the accumulation of $\mathrm{Al}$ in oil tea and inhibition of plant growth by $\mathrm{Al}$ toxicity. Root tip is the most sensitive root part to $\mathrm{P}$ deficiency and $\mathrm{Al}$ stress, and the mechanism through which $\mathrm{P}$ relieves root $\mathrm{Al}$ stress needs further study. We hypothesized that $\mathrm{P}$ application may mitigating $\mathrm{Al}$ toxicity by changing physiological and biochemical characteristic of oil tea roots. The aim of this study was to investigate the mitigation effect of $\mathrm{P}$ on $\mathrm{Al}$ induced oxidative damage and modification in the cell wall components of the roots of oil tea.

\section{Materials and Methods}

\section{Experiment treatments}

The experimental treatments were the same as previously described in Qu et al. (2020). Specifically, four-month-old healthy and uniform seedlings of $C$. oleifera 'Huajin' with $14-16 \mathrm{~cm}$ height were selected and planted in plastic pots filled with a mixture of sand and perlite. The seedlings were transformed into a greenhouse and grown at $28 / 22^{\circ} \mathrm{C}$ day/night temperature. The clear nutrient solution with $\mathrm{pH}$ 4.2 containing one of two $\mathrm{Al}\left(0\right.$ and $\left.4 \mathrm{mM} \mathrm{AlCl}{ }_{3} \cdot 6 \mathrm{H}_{2} \mathrm{O}\right)$ concentrations and one of two $\mathrm{P}(0.025$ and $0.5 \mathrm{mM}$ $\mathrm{KH}_{2} \mathrm{PO}_{4}$ ) concentrations were used to irrigate the seedlings. The components and concentrations of nutrient solution were chose according to Ghanati et al. (2005). The seedlings were randomly divided into four groups viz. $+\mathrm{P}-\mathrm{Al}(0 \mathrm{mM} \mathrm{Al}$ and $0.5 \mathrm{mM} \mathrm{P}),+\mathrm{P}+\mathrm{Al}(4 \mathrm{mM} \mathrm{Al}$ and $0.5 \mathrm{mM} \mathrm{P}),-\mathrm{P}-\mathrm{Al}(0 \mathrm{mM}$ $\mathrm{Al}$ and $0.025 \mathrm{mM} \mathrm{P})$, and $-\mathrm{P}+\mathrm{Al}(4 \mathrm{mM} \mathrm{Al}$ and $0.025 \mathrm{mM}$ $\mathrm{P})$. Each group consisted of three independent replications, and $+\mathrm{P}-\mathrm{Al}$ treatment was considered a control. A $1 \mathrm{mM} \mathrm{KCl}$ was used to compensate for $\mathrm{K}^{+}$concentration between -P and $+\mathrm{P}$ treatments. Seedlings were subjected to the above treatments for 8 weeks before termination of the experiment.

\section{Determination of relative root elongation and root activity}

Before and after eight-weeks of $\mathrm{P}$ and $\mathrm{Al}$ treatment, root length was assessed by WinRhizo Pro 2013 image analysis software after scanning root images by root scanner. Relative root elongation was assessed based on the root elongation under different $\mathrm{P}$ and $\mathrm{Al}$ treatments/root elongation in control treatment $\times 100 \%$. Root activity of oil tea root segments (0$10 \mathrm{~mm}$ ) was assayed using the triphenyl tetrazolium chloride (TTC) method (Gai et al. 2017).

\section{Histochemical analysis}

After $\mathrm{P}$ and $\mathrm{Al}$ treatment, the distribution of $\mathrm{Al}$ in roots was detected by staining with hematoxylin solution. Then, the roots were photographed under light stereomicroscopic microscope (Olympus SZX16) as described by Polle et al. 1978. Plasma membrane integrity of the roots was detected by staining with Evan's blue solution. Then, the roots were photographed under a light stereomicroscope (Yamamoto et al. 2001).

\section{Cell wall preparation, fractionation, and Al content determination}

The root cell wall (CW) was prepared according to Li et al. (2016). Root segments (1.0 g per replication) were homogenized and centrifuged at $4500 \times \mathrm{g}$. The precipitate was washed with $80 \%$ ethanol and methanol: chloroform $[1: 1 \quad(\mathrm{v} / \mathrm{v})]$ mixture followed by acetone. Then, the precipitate was dried at $60^{\circ} \mathrm{C}$ for further use. The dried powder was the crude cell wall.

Cell wall components were extracted sequentially from the crude cell wall according to the method of Yang et al. (2011). Pectin was first extracted with hot water; then hemicellulose 1 ( $\mathrm{HC} 1)$ was extracted with $4 \% \mathrm{KOH}$; hemicellulose 2 ( $\mathrm{HC} 2$ ) was extracted with $24 \% \mathrm{KOH}$; and the residue consisted mainly of cellulose.

The Al content in roots, cell walls, and pectin-free, $\mathrm{HC} 1$-free, and HC2-free fractions of cell walls was extracted by $2 \mathrm{M} \mathrm{HCl}$. The $\mathrm{Al}$ content was determined using the aluminum colorimetric method (Nieuwenburg and Uitenbroek 1948).

\section{Al adsorption in root cell wall fractions}

Roots in the $+\mathrm{P}-\mathrm{Al}$ and $-\mathrm{P}-\mathrm{Al}$ treatments were used for the $\mathrm{Al}$ adsorption experiment. Cell walls and the pectin-free, $\mathrm{HC} 1$-free, and $\mathrm{HC} 2$-free fractions of cell walls were placed in $15 \mathrm{~mL}$ centrifuge tubes, and then $5 \mathrm{~mL} 4 \mathrm{mM} \mathrm{AlCl} 3$ containing $0.5 \mathrm{mM} \mathrm{CaCl} 2$ at $\mathrm{pH} 4.2$ was added. The centrifuge tubes were shaken occasionally for $24 \mathrm{~h}$. After adsorption, the $\mathrm{Al}$ mixtures were subsequently centrifuged for $10 \mathrm{~min}$ at $4500 \times \mathrm{g}$. The $\mathrm{Al}$ content in the supernatant was determined using the aluminum colorimetric method. The concentrations of $\mathrm{Al}$ in pectin and $\mathrm{HCl}$ and $\mathrm{HC} 2$ fractions were calculated as above.

\section{Analysis of cell wall pectin and hemicellulose}

The pectin content was determined by M-hydroxybiphenyl colorimetry according to $\mathrm{Li}$ et al. (2016). The 
demethylesterfied pectin content was determined according to Louvet et al. (2011) at $620 \mathrm{~nm}$ using a spectrophotometer, and formaldehyde was used as the standard solution. The degree of pectin methyl esterification (DME) was calculated using the following equation.

$$
\operatorname{DME}(\%)=\left(\mathrm{C}_{\text {Methyl pectin }} / \mathrm{C}_{\text {Total pectin }}\right) \times 100 \text {. }
$$

The total sugar content in the HC1 and HC2 fractions was determined by anthrone colorimetry using glucose as a standard.

\section{PME, XET, and EGase activity assay}

For extraction of PME, roots (0.5 g per replicate) were homogenized using liquid $\mathrm{N}_{2}$ and were suspended in $5 \mathrm{~mL}$ extraction buffer $(1 \mathrm{M} \mathrm{NaCl}$ and $0.1 \mathrm{M}$ Tris at $\mathrm{pH}$ 7.5) at $4^{\circ} \mathrm{C}$ for $1 \mathrm{~h}$. Extracts were centrifuged and the supernatants were used to determine PME activity using the method of Anthon and Barrett (2004) based on the condensation of aldehyde with MBTH under neutral conditions.

The xyloglucan endotransglucosylase (XET) and endo- $\beta$-1,4-glucanases (EGase) activity were assayed by a plant xyloglucan endotransglucosylase ELISA testing kit and plant endo- $\beta$-1,4-glucanase ELISA testing kit (Shanghai Jianglai Biotechnology Co. Ltd.), respectively, according to the operating instructions.

\section{Assay of PAL, PPO activity, and soluble phenolic content}

Phenylalanine ammonia lyase (PAL) activity was assayed after extraction in $0.1 \mathrm{M} \mathrm{Na}_{2} \mathrm{~B}_{4} \mathrm{O}_{7}$ buffer containing $5 \mathrm{mM}$ 2-mercaptoethanol and $2 \%(\mathrm{w} / \mathrm{v})$ polyvinylpyrrolidone $(\mathrm{pH}$ 8.8). The reaction mixture comprised $1 \mathrm{~mL}$ enzyme extract, $2 \mathrm{~mL} 0.1 \mathrm{M} \mathrm{Na}_{2} \mathrm{~B}_{4} \mathrm{O}_{7}$ buffer ( $\mathrm{pH} \mathrm{8.8)}$, and $1 \mathrm{~mL} \mathrm{0.2} \mathrm{M} \mathrm{L-}$ phenylalanine. After incubation, the reaction was stopped with $0.1 \mathrm{~mL}$ of $5 \mathrm{M} \mathrm{HCl}$. The absorbance was assayed at $290 \mathrm{~nm}$ (Wang and Huang 2015). Polyphenol oxidase (PPO) activity was determined by calculating the oxidation of catechol according to Singh et al. (1999). Soluble phenolics were extracted with aqueous methanol and determined with Folin-Ciocalteu reagent using gallic acid as a standard (Morrison 1972).

\section{Antioxidant enzyme activity, free proline and $\mathrm{H}_{2} \mathrm{O}_{2}$ content assays}

Superoxide dismutase (SOD) activity, peroxidase (POD) activity, catalase (CAT) activity, and free proline content were determined using the method of Wang and Huang (2015). Ascorbate peroxidase (APX) activity was determined using the method of Nakano and Asada (1981). The $\mathrm{H}_{2} \mathrm{O}_{2}$ content was determined using the xylenol orange method according to Zhang et al. (2016).

\section{Statistical analysis}

Experiments were carried out using a complete randomized block design with three replications. Data were analyzed using the statistical program SPSS software (version 22.0).

\section{Results}

Effect of $\mathbf{P}$ and $\mathrm{Al}$ on relative root elongation, root activity and plasma membrane integrity

Compared to the control $(+\mathrm{P}-\mathrm{Al})$, the relative root elongation decreased significantly in the $-\mathrm{P}+\mathrm{Al}$ treatment (Fig. 1a). The $+\mathrm{P}+\mathrm{Al}$ treatment significantly increased the relative root elongation by $58.97 \%$ compared to the $-\mathrm{P}+\mathrm{Al}$ treatment. Combined $\mathrm{P}$ deficiency and $\mathrm{Al}$ stresses decreased root activity significantly, while $\mathrm{P}$ addition $(+\mathrm{P}+\mathrm{Al})$ significantly increased the root activity by $52.09 \%$ (Fig. 1b). To visualize the loss of plasma membrane integrity, we used the Evans blue dye to staining the roots under different treatments. Evan's blue staining showed that $-\mathrm{P}+\mathrm{Al}$ treatment was stronger and showed greater damage to the plasma membrane than the $+\mathrm{P}-\mathrm{Al}$ treatment (Fig. 1c). The $+\mathrm{P}+\mathrm{Al}$ treatment showed weaker staining than the $-\mathrm{P}+\mathrm{Al}$ treatment, which indicated the decrease in plasma membrane damage.

\section{Effect of $P$ on the $\mathrm{Al}$ content in the roots}

Hematoxylin staining results qualitatively demonstrated the $\mathrm{Al}$ distribution by a purple color (Fig. 2a). The color of roots in the $-\mathrm{P}+\mathrm{Al}$ treatment was darker than that in the $+\mathrm{P}+\mathrm{Al}$ treatment, indicating that roots in the $-\mathrm{P}+\mathrm{Al}$ treatment had higher $\mathrm{Al}$ accumulation than those in the $+\mathrm{P}+\mathrm{Al}$ treatment. To confirm the distribution of $\mathrm{Al}$ in roots, we assayed the $\mathrm{Al}$ content in roots and root cell walls. $\mathrm{Al}$ content in roots and cell walls significantly increased in $+\mathrm{Al}$ treatments than in $\mathrm{Al}$ treatments (Fig. 2b). Interestingly, $\mathrm{P}$ application under $\mathrm{Al}$ stress significantly decreased $\mathrm{Al}$ content in roots and root cell walls compared to $-\mathrm{P}+\mathrm{Al}$ treatment. More than $55 \%$ of $\mathrm{Al}$ in roots was located in the cell wall (Fig. 2c). The distribution ratio of $\mathrm{Al}$ in the cell wall was nearly $80 \%$ higher in $+\mathrm{Al}$ treatments than in $-\mathrm{Al}$ treatments.

\section{Effect of $\mathbf{P}$ on $\mathrm{Al}$ allocation and adsorption in root cell wall fractions}

To further confirm the effect of $\mathrm{P}$ on the distribution of $\mathrm{Al}$ in cell wall components, we measured the $\mathrm{Al}$ accumulation in different cell wall components under $-\mathrm{P}+\mathrm{Al}$ and $+\mathrm{P}+\mathrm{Al}$ treatments. The results showed that most of the $\mathrm{Al}$ (about $80 \%$ ) in cell walls accumulated in pectin and $\mathrm{HC} 1$ (Table 1). The $\mathrm{Al}$ content in pectin and $\mathrm{HC} 1$ decreased under $\mathrm{P}$ addition. The proportion of $\mathrm{Al}$ in pectin decreased to $40.51 \%$ from $45.48 \%$ under $P$ addition.

The effect of $\mathrm{P}$ on $\mathrm{Al}$ adsorption in different cell wall components showed that pectin and $\mathrm{HC} 1$ adsorbed more $\mathrm{Al}$ compared with $\mathrm{HC} 2$ and cellulose (Table 2). The adsorption of $\mathrm{Al}$ to pectin and $\mathrm{HC} 1$ fraction with $\mathrm{P}$ supply was lower than that under the $\mathrm{P}$ deficiency. 
Qu et al. / Intl J Agric Biol, Vol 25, No 3, 2021

Table 1: Effect of $\mathrm{P}$ on the $\mathrm{Al}$ content in different cell wall components of $+\mathrm{Al}$ treatments of oil tea roots

\begin{tabular}{lllll}
\hline Treatment & \multicolumn{4}{c}{ Al content in different cell wall components $(\mathrm{mg} / \mathrm{kg})$} \\
\cline { 2 - 5 } & Pectin & HC1 & HC2 & Cellulose \\
\hline$-\mathrm{P}$ & $243.43 \pm 12.90 \mathrm{a}$ & $188.46 \pm 0.98 \mathrm{a}$ & $50.48 \pm 2.74 \mathrm{a}$ & $51.06 \pm 7.79 \mathrm{a}$ \\
& $(45.48 \pm 0.32 \%)$ & $(35.27 \pm 1.47 \%)$ & $(9.43 \pm 0.10 \%)$ & $(9.82 \pm 1.10 \%)$ \\
$+\mathrm{P}$ & $189.37 \pm 26.10 \mathrm{~b}$ & $175.08 \pm 2.42 \mathrm{~b}$ & $48.47 \pm 4.35 \mathrm{a}$ & $53.19 \pm 10.01 \mathrm{a}$ \\
& $(40.51 \pm 1.99 \%)$ & $(37.74 \pm 2.97 \%)$ & $(10.41 \pm 0.46 \%)$ & $(11.34 \pm 1.18 \%)$ \\
\hline
\end{tabular}
sample $t$ test $(P<0.05)$

Table 2: The effect of $\mathrm{P}$ on the adsorption of $\mathrm{Al}$ in different cell wall components of oil tea roots

\begin{tabular}{llll}
\hline Treatment & & Adsorption of Al in different cell wall components (mg/kg) \\
\cline { 2 - 3 } & Pectin & HC1 & HC2 \\
\hline$-\mathrm{P}$ & $186.35 \pm 5.17 \mathrm{a}$ & $196.81 \pm 0.95 \mathrm{a}$ & $26.14 \pm 5.19 \mathrm{a}$ \\
$+\mathrm{P}$ & $162.24 \pm 12.60 \mathrm{~b}$ & $177.31 \pm 2.81 \mathrm{~b}$ & $21.07 \pm 2.19 \mathrm{a}$ \\
\hline Values $($ mean $\pm \mathrm{SD}, \mathrm{n}=3)$ & with different letters indicate significant differences between $-\mathrm{P}$ and $+\mathrm{P}$ treatments within the same cell wall component according to an Independent \\
sample $t$ test $(P<0.05)$ & &
\end{tabular}

$\mathbf{a}$
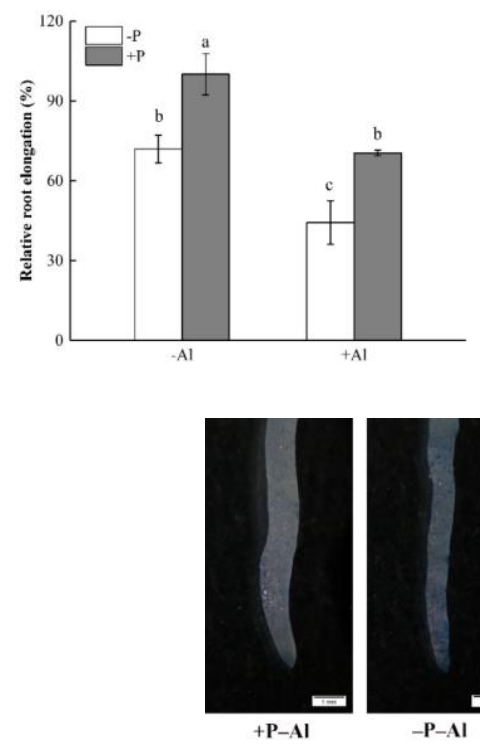
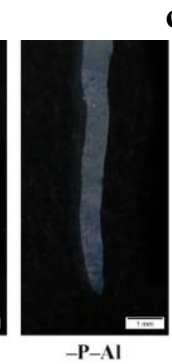

b
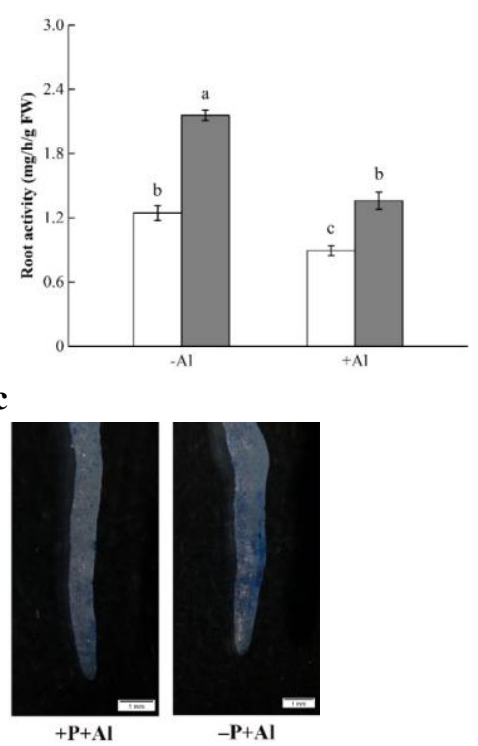

Fig. 1: Effect of $\mathrm{P}$ and $\mathrm{Al}$ on relative root elongation (a), root activity (b), and plasma membrane integrity (c) in oil tea roots. Error bars indicate the SD; different letters above error bars indicate significant differences at $P<0.05$ according to Duncan's test

\section{Effect of $P$ and $A l$ on pectin properties}

Exposure to $\mathrm{Al}$ resulted in a significant increase in pectin, of $94.37 \%$ and $58.27 \%$ under $\mathrm{P}$ supply and $\mathrm{P}$ deficiency, respectively (Fig. 3a). P deficiency also induced an increase in the pectin content regardless of $\mathrm{Al}$ presence. The degree of pectin methyl esterification (DME) was at a high level without Al supply, whereas the Al stress significantly decreased DME to $32.23 \%$ and $20.26 \%$ under $-\mathrm{P}$ and $+\mathrm{P}$ treatments, respectively (Fig. 3b). However, application of $\mathrm{P}$ significantly decreased the DME under Al toxicity. Al toxicity significantly increased the demethylesterified pectin content by 4.78and 4.27-folds under $\mathrm{P}$ deficiency and $\mathrm{P}$ supply, respectively (Fig. 3c). $\mathrm{P}$ application under $\mathrm{Al}$ toxicity decreased the demethylesterified pectin content significantly. P application under Al toxicity significantly decreased the PME activity, though Al stress slightly increased the PME activity under P deficiency (Fig. 3d).

\section{Variations in hemicellulose content in response to $\mathbf{P}$ and Al treatment}

The content of HC1 increased in oil tea after Al supply (Fig. 4a). After P application, the $\mathrm{HC} 1$ content in roots decreased significantly under $\mathrm{Al}$ stress. The content of $\mathrm{HC} 2$ was not significantly affected by $\mathrm{P}$ and $\mathrm{Al}$ treatments (Fig. 4b). The $\mathrm{P}+\mathrm{Al}$ treatment significantly decreased the XET and EGase activities by $24.67 \%$ and $30.57 \%$, respectively, compared to the $+\mathrm{P}-\mathrm{Al}$ treatment (Fig. 4c-d). However, the application of $\mathrm{P}$ under $\mathrm{Al}$ toxicity reduced the inhibition of XET and EGase activities. 

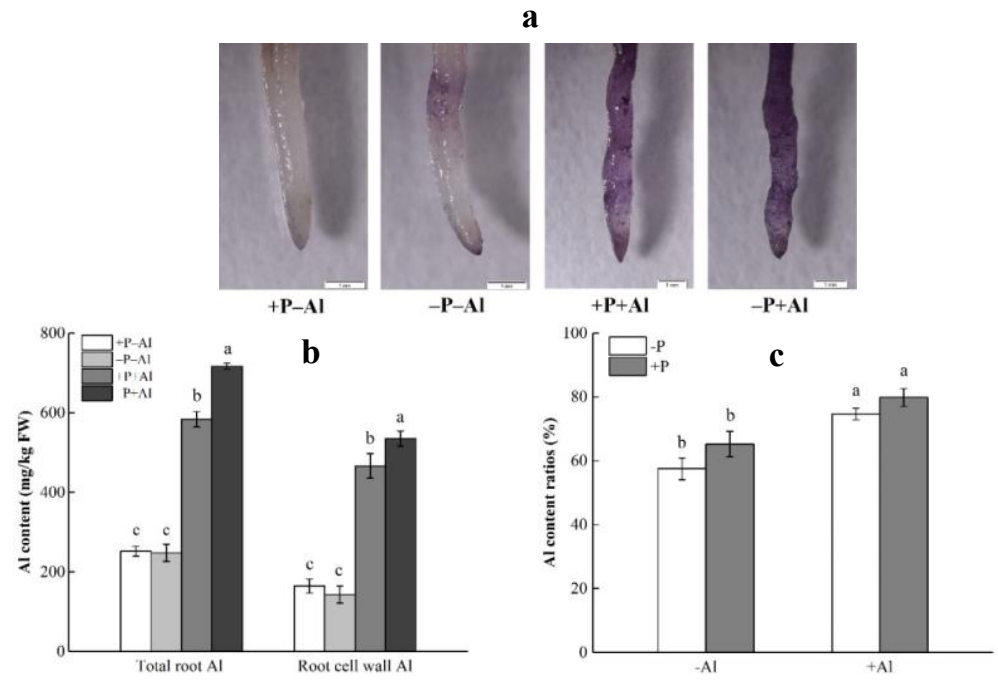

Fig. 2: The distribution of $\mathrm{Al}$ in roots of oil tea under different $\mathrm{P}$ and $\mathrm{Al}$ treatments. (a) The distribution of $\mathrm{Al}$ in roots was determined by hematoxylin staining. (b) The content of $\mathrm{Al}$ in roots and their cell walls. (c) The $\mathrm{Al}$ content ratios were calculated using the ratio of $\mathrm{Al}$ content in root cell walls and roots. Error bars indicate the SD; different letters above error bars indicate significant differences at $P<0.05$ according to Duncan's test
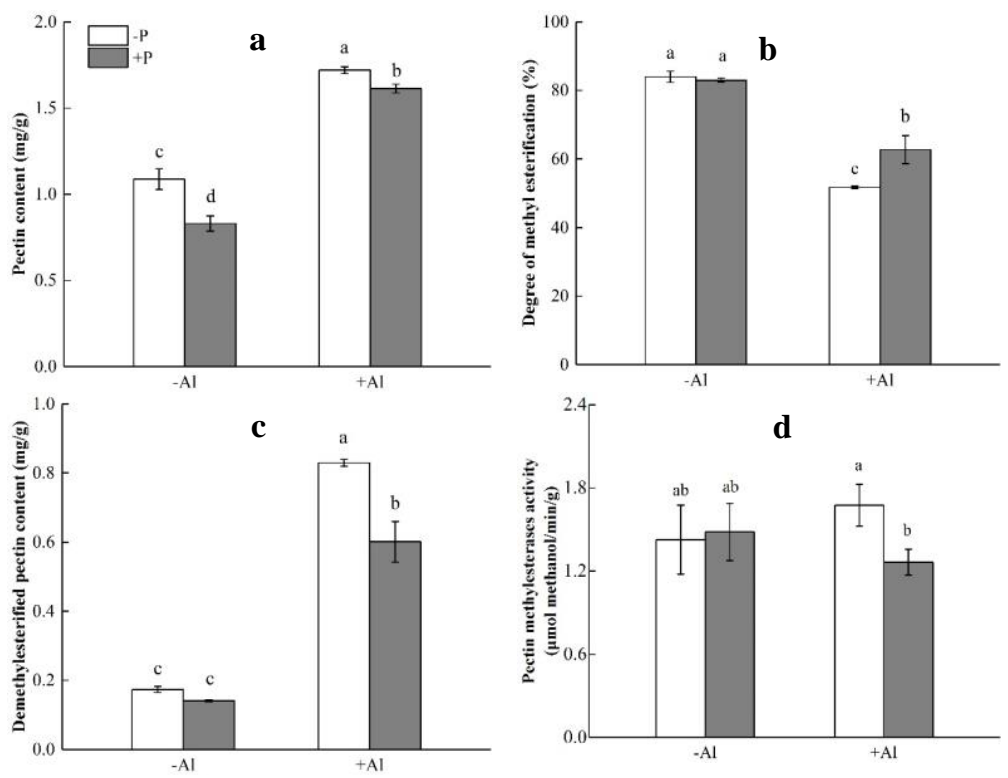

Fig. 3: Effect of $\mathrm{P}$ and $\mathrm{Al}$ on the pectin content (a), degree of pectin methyl esterification (b), demethylesterified pectin content (c), and PME activity (d). Error bars indicate the SD; different letters above error bars indicate significant differences at $P<0.05$ according to Duncan's test

\section{Effect of P and Al on the PAL and PPO activities and soluble phenolic content}

On the condition of P deficiency, the PAL and PPO activities increased significantly under $\mathrm{Al}$ stress compared to the control (+P-Al) plants (Fig. 5a-b). However, P application significantly decreased the PAL and PPO activities under Al stress. Soluble phenolic content was increased under $\mathrm{Al}$ stress, and the supply of $\mathrm{P}$ did not significantly change the soluble phenolic content under $\mathrm{Al}$ stress (Fig. 5c).

\section{Effect of $\mathrm{P}$ and $\mathrm{Al}$ on free proline and $\mathrm{H}_{2} \mathrm{O}_{2}$ contents and antioxidant enzyme activities}

Phosphorus deficiency significantly decreased the activity of SOD in oil tea roots regardless of $\mathrm{Al}$ stress (Fig. 6a). The $-\mathrm{P}+\mathrm{Al}$ treatment significantly decreased the activities of APX and CAT (Fig. 6b-c). However, the $+\mathrm{P}+\mathrm{Al}$ treatment increased APX and CAT activities by $11.37 \%$ and $37.04 \%$, respectively, compared to the $-\mathrm{P}+\mathrm{Al}$ treatment. $\mathrm{Al}$ stress significantly decreased the activity of POD regardless of $\mathrm{P}$ 
Qu et al. / Intl J Agric Biol, Vol 25, No 3, 2021
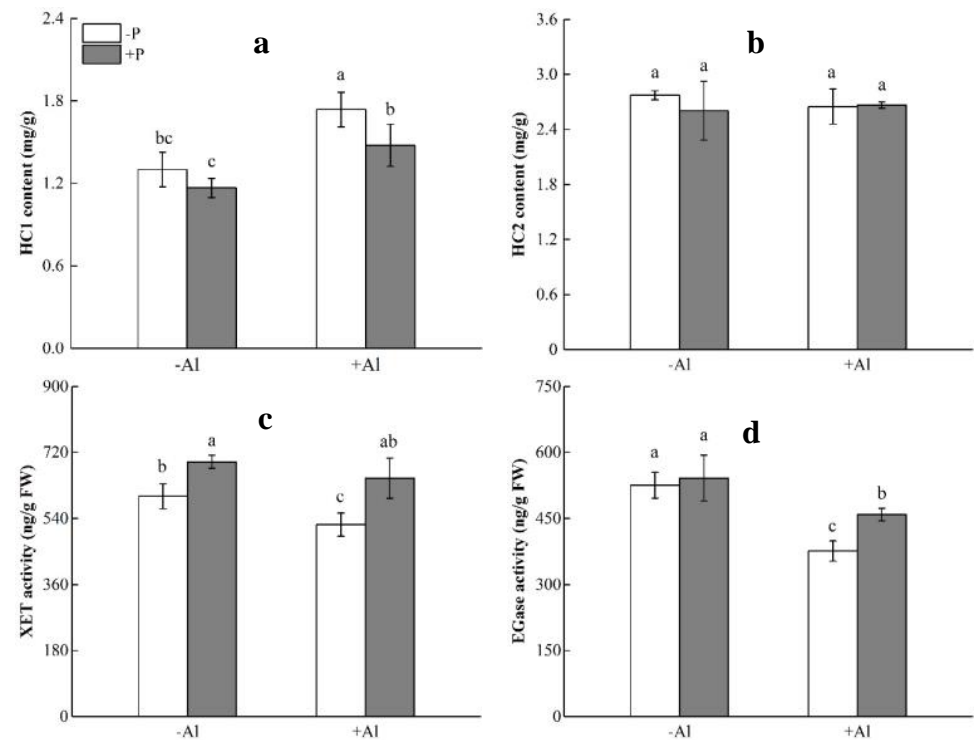

Fig. 4: Effect of $\mathrm{P}$ and $\mathrm{Al}$ on hemicellulose ( $\mathrm{HC} 1$ and $\mathrm{HC} 2)$ content and XET and EGase activities. Error bars indicate the SD; different letters above error bars indicate significant differences at $P<0.05$ according to Duncan's test
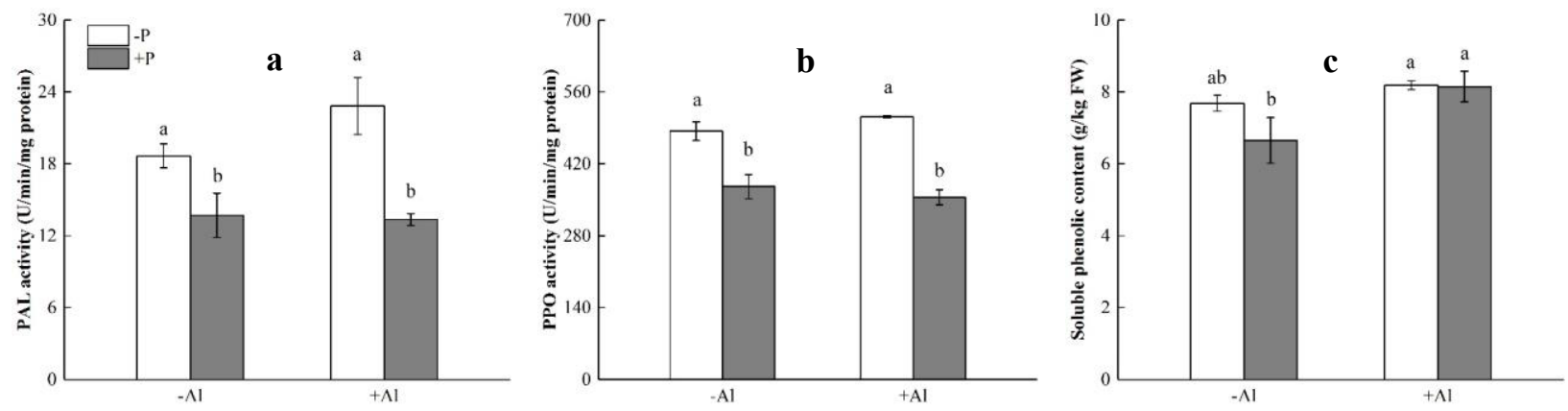

Fig. 5: Effect of $\mathrm{P}$ and $\mathrm{Al}$ on the activities of $\mathrm{PAL}$ and $\mathrm{PPO}$ and the content of soluble phenolic in oil tea roots. Error bars indicate the SD; different letters above error bars indicate significant differences at $P<0.05$ according to Duncan's test

addition compared to the $+\mathrm{P}-\mathrm{Al}$ treatment (Fig. 6d). Al stress significantly increased $\mathrm{H}_{2} \mathrm{O}_{2}$ content regardless of $\mathrm{P}$ application, while the $+\mathrm{P}+\mathrm{Al}$ treatment decreased the $\mathrm{H}_{2} \mathrm{O}_{2}$ content compared to the $-\mathrm{P}+\mathrm{Al}$ treatment (Fig. 6e). The $\mathrm{P}+\mathrm{Al}$ treatment significantly increased the free proline content, while $\mathrm{P}$ application under $\mathrm{Al}$ stress decreased the free proline content (Fig. 6f).

\section{Discussion}

In this study, $\mathrm{Al}$ stress under $\mathrm{P}$ deficiency significantly inhibited the relative root elongation rate, decreased root activity, and destroyed the plasma membrane integrity in oil tea roots. However, the appreciable improvement in root elongation, root activity, and plasma membrane integrity by $\mathrm{P}$ application under $\mathrm{Al}$ toxicity, indicating that $\mathrm{P}$ is involved in alleviating the $\mathrm{Al}$ stress. Roots are the first site of metal absorption and accumulation in many plants. Many studies revealed that $\mathrm{Al}$ stress inhibited relative root elongation mainly due to the accumulation of $\mathrm{Al}$ in the roots (Riaz et al. 2018b; Zhu et al. 2019). Reducing the accumulation of $\mathrm{Al}$ in roots will relieve the disruption and severe lesions in the root elongation zone caused by the accumulation of a large amount of Al in root tips (Mukhopadyay et al. 2012; Kopittke et al. 2015). Increasing evidence indicates that the cell wall is a major target of $\mathrm{Al}$ accumulation in plant roots, and reducing the $\mathrm{Al}$ content in the cell wall could alleviate root elongation inhibition by $\mathrm{Al}$ stress ( $\mathrm{Li}$ et al. 2017b; Safari et al. 2018; Zhu et al. 2019). Our results revealed that the cell wall was the main site of $\mathrm{Al}$ accumulation in roots and nearly $80 \%$ of $\mathrm{Al}$ distributed in cell wall when exposed to $\mathrm{Al}$, consistent with observations reported by $\mathrm{Li}$ et al. (2017a) for tea. Roots in the -P+Al treatment were more susceptible to $\mathrm{Al}$ than those in the $+\mathrm{P}+\mathrm{Al}$ treatment, and the application of $\mathrm{P}$ decreased the accumulation of $\mathrm{Al}$ in roots and cell walls (Fig. 2a-b).

Current increasing physiological and biochemical evidence shows that the adsorption of $\mathrm{Al}$ to the cell wall is associated with polysaccharides in cell walls $(\mathrm{Li}$ et al. 2017b; Safari et al. 2018). The ability of cell wall fractions 

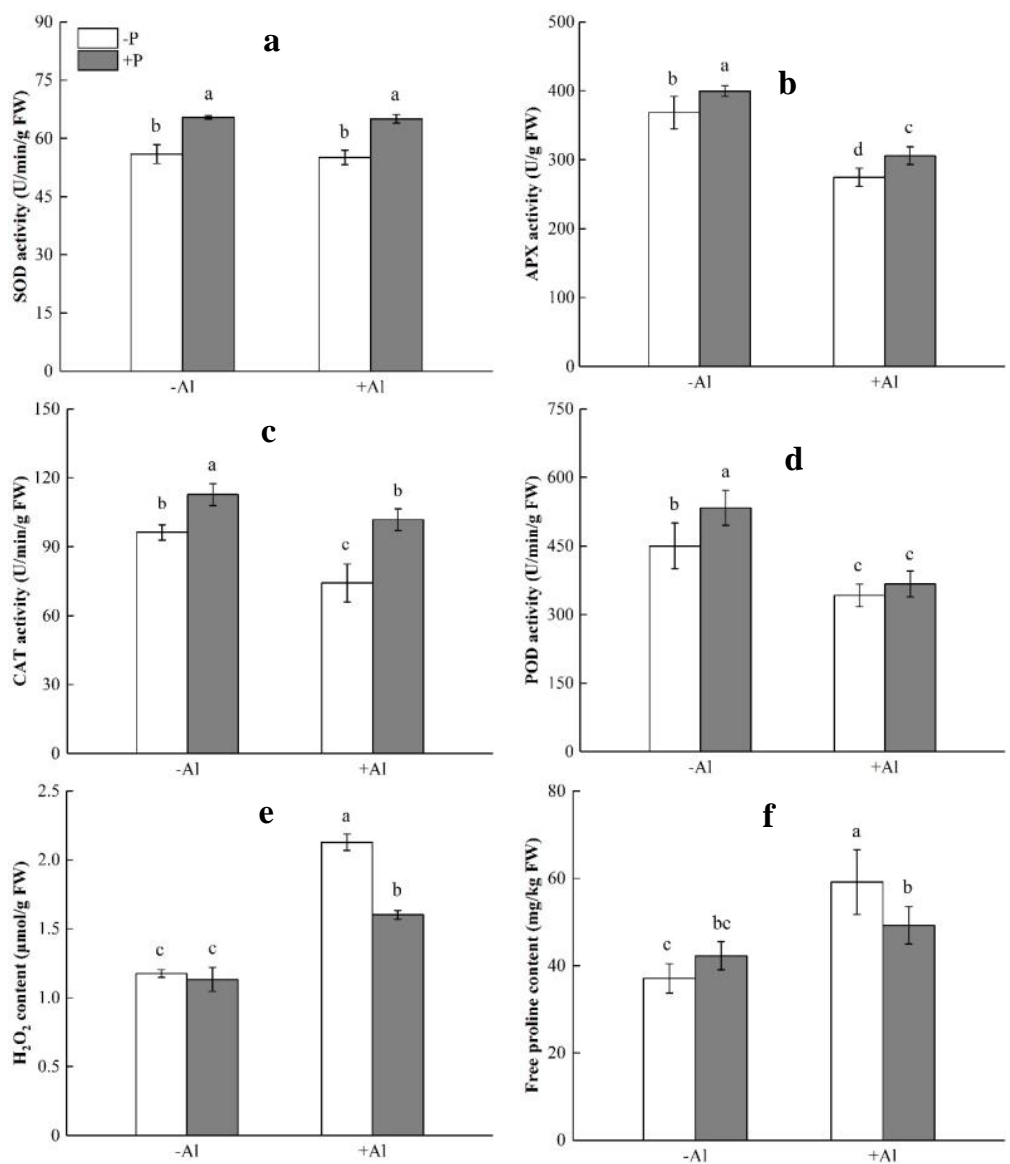

Fig. 6: Effect of $\mathrm{P}$ and $\mathrm{Al}$ on the activities of SOD, APX, CAT, and POD and the content of $\mathrm{H}_{2} \mathrm{O}_{2}$ and free proline in oil tea roots. Error bars indicate the SD; different letters above error bars indicate significant differences at $P<0.05$ according to Duncan's test

to bind with $\mathrm{Al}$ was determined in our study (Table 1). The pectin fraction has a large number of negatively charged carboxylic groups that can easily chelate $\mathrm{Al}$, and plants with higher pectin content in roots have a greater potential to accumulate $\mathrm{Al}$ (Horst et al. 2010). However, the actual $\mathrm{Al}$ accumulation capacity of pectin depends on both the pectin content and the degree of pectin methylesterification ( $\mathrm{Li}$ et al. 2016). Al stress increased the pectin content in oil tea roots (Fig. 3), while the $-\mathrm{P}+\mathrm{Al}$ treatment resulted in a higher cell wall demethylesterified pectin content and a lower degree of pectin methylesterification in oil tea roots (Fig. 3). Interestingly, $\mathrm{P}$ application significantly decreased the pectin content, especially the demethylesterified pectin content, and increased the degree of pectin methylesterification, which significantly reduced the binding sites of $\mathrm{Al}$. It has been reported that plant resistance to $\mathrm{Al}$ is negatively related to PME activity (Zhu et al. 2012). Therefore, the decreased $\mathrm{Al}$ content in the pectin fraction may further be due to the lower PME activity under the $+\mathrm{P}+\mathrm{Al}$ treatment (Fig. 3).

For a long time, the investigations of root cell wall responses to $\mathrm{Al}$ stress were focused on the properties of pectin, while recent studies pointed out that the hemicellulose as the second wall component was very susceptible to $\mathrm{Al}$ stress (Safari et al. 2018). It is shown that hemicellulose content was enhanced significantly under Al stress (Zhu et al. 2019), and Yang et al. (2011) showed that hemicellulose was the principal binding site of $\mathrm{Al}$ in Arabidopsis. Our result showed that the $-\mathrm{P}+\mathrm{Al}$ treatment significantly increased the $\mathrm{HC} 1$ content, while the $\mathrm{HC} 1$ content and $\mathrm{Al}$ content in $\mathrm{HC} 1$ decreased with $\mathrm{P}$ application. A decrease in the $\mathrm{HC} 1$ content may decrease the binding sites of Al. The modification of hemicellulose polysaccharides, such as xyloglucan, affects wall loosening and expansion (Safari et al. 2018). Our results showed that $\mathrm{P}$ application reduced the inhibition of XET and EGase activities by $\mathrm{Al}$ stress (Fig. 4). The increase in XET activity catalyzed the splitting of xyloglucan chains, and an increase in EGase activity hydrolyzed $\beta-1,4$ glucan bonds to loosen the xyloglucan-cellulose network, thereby loosening the cell wall and promoting the elongation of roots (Yang et al. 2011; Safari et al. 2018).

PAL is a key enzyme involved in the biosynthesis of phenolic compounds and shows a positive response to various stress conditions (Hajiboland et al. 2015). However, the increase in PPO activity is able to promote the oxidation of phenolic to quinones, which in turn produce ROS and are 
toxic to cells (Yoruk and Marshall 2003). It has been reported that $\mathrm{Al}$ stress can increase the activities of PAL and PPO and enhance the oxidative stress of cells, thus disrupting the intracellular environmental stability (Riaz et al. 2018a). Our results show that the addition of $\mathrm{P}$ effectively reduced the activities of PAL and PPO, thereby reducing the production of harmful substances. Studies have shown that $\mathrm{Al}$ stress can induce the production of soluble phenolic and the application of ${ }^{27} \mathrm{Al}$-nuclear magnetic resonance identified the Al-catechin complex in cell sap, which reduced the damage caused by $\mathrm{Al}^{3+}$ to organelles inside the protoplast (Morita et al. 2008; Hajiboland et al. 2013). Our results indicated that the addition of $\mathrm{Al}$ significantly increased the content of soluble phenolic regardless of $\mathrm{P}$ application, which may be used for chelating Al in cell sap.

It has been reported that ionic stress such as $\mathrm{P}$ deficiency and $\mathrm{Al}$ toxicity breaks down the balance between antioxidant enzymes and ROS, resulting in oxidantive damage and growth inhibition of plants (Yu et al. 2018; Zhou et al. 2019). The working mechanism of antioxidant enzymes is that SOD converts the excess superoxide radical into $\mathrm{H}_{2} \mathrm{O}_{2}$, and POD, CAT, and APX decompose $\mathrm{H}_{2} \mathrm{O}_{2}$ into $\mathrm{H}_{2} \mathrm{O}$ and $\mathrm{O}_{2}$ (Wang et al. 2009). The results showed that $\mathrm{P}+\mathrm{Al}$ treatment inhibited the activities of antioxidant enzymes, which resulted in the overproduction of $\mathrm{H}_{2} \mathrm{O}_{2}$ and ultimately led to oxidative damage, and the plasma membrane integrity of cells was destroyed. The $\mathrm{P}$ addition decreased the $\mathrm{H}_{2} \mathrm{O}_{2}$ content and increased the activities of antioxidant enzymes. Proline is an important osmoregulator that can be induced by abiotic stress such as heavy metal toxicity and water deficit (Hou et al. 2016; Qu et al. 2019). $\mathrm{P}$ application significantly decreased the free proline content under $\mathrm{Al}$ stress, which further confirmed that $\mathrm{P}$ application decreased the toxicity of $\mathrm{Al}$ to roots.

\section{Conclusion}

The present study demonstrated that $\mathrm{Al}$ stress severely inhibited root elongation by inducing variations in the cell wall components as well as oxidative damage in roots of oil tea. However, $\mathrm{P}$ supply promoted root elongation. The mechanism could be summarized as follows: (1) P application reduced the accumulation of $\mathrm{Al}$ in cell walls by decreasing de-methyl esterified pectin content and $\mathrm{HC} 1$ content to decrease $\mathrm{Al}$ binding sites; (2) P application under $\mathrm{Al}$ stress enhanced cell wall loosening by alleviating the inhibition of XET and EGase activities; (3) P application eliminated oxidative damage by inhibiting the activities of PAL and PPO and by enhancing the activities of ROS scavenging enzymes.

\section{Acknowledgement}

This research was funded by Provincial Science and Technology Major Project of Hunan, China under Grant, grant number 2018NK1030.

\section{Author Contributions}

Xinjing $\mathrm{Qu}$, carried out the experiment, collected and organized data, and wrote the manuscript. Jiao Liao and Chenhui Zhang carried out the experiment, collected and organized data. Jun Yuan raised the hypothesis underlying this work, designed the experiment, and reviewed the manuscript. All authors have read and approved the final manuscript.

\section{References}

Anthon GE, DM Barrett (2004). Comparison of three colorimetric reagents in the determination of methanol with alcohol oxidase. Application to the assay of pectin methylesterase. J Agric Food Chem 52:37493753

Gai Z, J Zhang, C Li (2017). Effects of starter nitrogen fertilizer on soybean root activity, leaf photosynthesis and grain yield. PLoS One 12; Article 0174841

Ghanati F, A Morita, H Yokota (2005). Effects of aluminum on the growth of tea plant and activation of antioxidant system. Plant Soil 276:133-141

Hajiboland R, S Bahrami Rad, J Barceló, C Poschenrieder (2013). Mechanisms of aluminum-induced growth stimulation in tea (Camellia sinensis). J Plant Nutr Soil Sci 176:616-625

Hajiboland R, S Bahrami Rad, S Bastani (2015). Phenolics metabolism in boron-deficient tea [Camellia sinensis (L.) O. Kuntze] plants. Acta Biol Hung 64:196-206

Horst WJ, Y Wang, D Eticha (2010). The role of the root apoplast in aluminum-induced inhibition of root elongation and in aluminum resistance of plants: A review. Ann Bot 106:185-197

Hou W, H Hu, Y Lu, T Li, W Teng, L Wang (2016). Relieve effect of exogenous $\mathrm{P}$ on the eucalyptus growth and physiological feature under Al stress. J Northeast For Univ 44:5-9

Kochian LV, OA Hoekenga, MA Piñeros (2004). How do crop plants tolerate acid soils? Mechanisms of aluminum tolerance and phosphorous efficiency. Annu Rev Plant Biol 55:459-493

Kopittke PM, KL Moore, E Lombi, A Gianoncelli, BJ Ferguson, FP Blamey, NW Menzies, TM Nicholson, BA McKenna, P Wang, PM Gresshoff, G Kourousias, RI Webb, K Green, A Tollenaere (2015). Identification of the primary lesion of toxic aluminum in plant roots. Plant Physiol 167:1402-1411

Li D, Z Shu, X Ye, J Zhu, J Pan, W Wang, P Chang, C Cui, J Shen, W Fang, X Zhu, Y Wang (2017a). Cell wall pectin methyl-esterification and organic acids of root tips involve in aluminum tolerance in Camellia sinensis. Plant Physiol Biochem 119:265-274

Li X, Y Li, M Qu, H Xiao, Y Feng, J Liu, L Wu, M Yu (2016). Cell wall pectin and its methyl-esterification in transition zone determine $\mathrm{Al}$ resistance in cultivars of Pea (Pisum sativum). Front Plant Sci 2016; Article 00039

Li X, J Liu, J Fang, L Tao, R Shen, Y Li, H Xiao, Y Feng, H Wen, J Guan, L Wu, Y He, HE Goldbach, M Yu (2017b). Boron supply enhances aluminum tolerance in root border cells of Pea (Pisum sativum) by interacting with cell wall pectins. Front Plant Sci 2017; Article 00742

Louvet R, C Rayon, JM Domon, C Rusterucci, F Fournet, A Leaustic, MJ Crépeau, MC Ralet, C Rihouey, M Bardor, P Lerouge, F Gillet, J Pelloux (2011). Major changes in the cell wall during silique development in Arabidopsis thaliana. Phytochemistry 72:59-67

Mo X, M Zhang, C Liang, L Cai, J Tan (2019). Integration of metabolome and transcriptome analyses highlights soybean roots responding to phosphorus deficiency by modulating phosphorylated metabolite processes. Plant Physiol Biochem 139:697-706

Morita A, O Yanagisawa, S Takatsu, S Maeda, S Hiradate (2008). Mechanism for the detoxification of aluminum in roots of tea plant (Camellia sinensis (L.) Kuntze). Phytochemistry 69:147-153

Morrison IM (1972). A semi-micro method for the determination of lignin and its use in prediction the digestibility of forage crops. J Sci Food Agric 23:455-463 
Mukhopadyay M, P Bantawa, A Das, B Sarkar, B Bera, P Ghosh, T Kumar Mondal (2012). Changes of growth, photosynthesis and alteration of leaf antioxidative defence system of tea [Camellia sinensis (L.) O. Kuntze] seedlings under aluminum stress. Biometals 25:11411154

Nagarajah S, AM Posner, JP Quirk (1970). Competitive adsorption of phosphate with polygalacturonate and other organic anions on kaolinate and oxide surface. Nature 228:83-84

Nakano Y, K Asada (1981). Hydrogen peroxide is scavenged by ascorbate specific peroxidase in spinach chloroplasts. Plant Cell Physiol 22:867-880

Nieuwenburg CJV, G Uitenbroek (1948). On the detection of aluminium by means of aluminon. Anal Chim Acta 2:88-91

Polle E, C Konzak, J Kittrick (1978). Visual detection of aluminum tolerance levels in wheat by hematoxylin staining of seedling roots. Crop Sci 18:823-827

Qu X, H Wang, M Chen, J Liao, J Yuan, G Niu (2019). Drought stressinduced physiological and metabolic changes in leaves of two oil tea cultivars. J Amer Soc Hortic Sci 144:439-447

Qu X, J Zhou, J Masabni, J Yuan (2020). Phosphorus relieves aluminum toxicity in oil tea seedlings by regulating the metabolic profiling in the roots. Plant Physiol Biochem 152:12-22

Riaz M, L Yan, X Wu, S Hussain, O Aziz, Y Wang, M Imran, C Jiang (2018a). Boron alleviates the aluminum toxicity in trifoliate orange by regulating antioxidant defense system and reducing root cell injury. J Environ Manage 208:149-158

Riaz M, L Yan, X Wu, S Hussain, O Aziz, M Imran, MS Rana, C Jiang (2018b). Boron reduces aluminum-induced growth inhibition, oxidative damage and alterations in the cell wall components in the roots of trifoliate orange. Ecotox Environ Safe 153:107-115

Safari M, F Ghanati, MR Safarnejad, NA Chashmi (2018). The contribution of cell wall composition in the expansion of Camellia sinensis seedlings roots in response to aluminum. Planta 247:381-392

Singh N, R Singh, K Kaur, H Singh (1999). Studies of the physico-chemical properties and polyphenoloxidase activity in seeds from hybrid sunflower (Helianthus annuиs) varieties grown in India. Food Chem 66:241-247
Wang X, J Huang (2015). Principle and Technology of Plant Physiological and Biochemical Experiments, $3^{\text {rd }}$ edn. Higher Education Press, Beijing, China

Wang X, P Liu, H Luo, Z Xie, G Xu, J Yao, K Chen (2009). Effect of Al and $F$ interaction on physiological characteristics of tea plants. Acta Hort Sin 36:1359-1364

Yamamoto Y, Y Kobayashi, H Matsumoto (2001). Lipid peroxidation is an early symptom triggered by aluminum, but not the primary cause of elongation inhibition in pea roots. Plant Physiol 125:199-208

Yang C, X Liu, Z Chen, Y Lin, S Wang (2016). Comparison of oil content and fatty acid profile of ten new Camellia oleifera cultivars. J Lipids 2016; Article 3982486

Yang L, X Zhu, Y Peng (2011). Cell wall hemicellulose contributes significantly to aluminum adsorption and root growth in Arabidopsis. Plant Physiol 155:1885-1892

Yu J, L Xia, D Yin, C Zhou (2018). Effects of phosphorus on aluminum tolerance of Chinese fir seedlings. Sci Silvae Sin 54:36-47

Yoruk R, MR Marshall (2003). Physicochemical properties and function of plant polyphenol oxidase: A review. J Food Biochem 27:361-422

Zhang Z, W Qu, X Li (2016). Experimental Guidance on Plant Physiology, $4^{\text {th }}$ edn. Higher Education Press, Beijing, China

Zhao X, X Zhu, Q Wu, R Shen (2018). Study on mechanism of demethylation of pectin promoting reutilization of cell wall phosphorus in Rice (Oryza sativa) root. Acta Pedol Sin 55:1190-1198

Zhou J, Z Ai, H Wang, G Niu, J Yuan (2019). Phosphorus alleviates aluminum toxicity in Camellia oleifera seedlings. Intl J Agric Biol $21: 237-243$

Zhu C, X Cao, Z Bai, L Zhu, W Hu, A Hu, B Abliz, C Zhong, Q Liang, J Huang, J Zhang, Q Jin (2019). Putrescine alleviates aluminum toxicity in rice (Oryza sativa) by reducing cell wall $\mathrm{Al}$ contents in an ethylene-dependent manner. Physiol Plantarum 167:471-487

Zhu X, G Lei, T Jiang, Y Liu, X Li, S Zheng (2012). Cell wall polysaccharides are involved in P-deficiency-induced $\mathrm{Cd}$ exclusion in Arabidopsis thaliana. Planta 236:989-997

Zhu X, Z Wang, J Wan, Y Sun, Y Wu, G Li, R Shen, S Zheng (2015). Pectin enhances rice (Oryza sativa) root phosphorus remobilization. $J$ Exp Bot 66:1017-1024 